\title{
RESPONSE OF WESTERN FLOWER THRIPS TO VISUAL AND ODOUR CUES IN A WIND TUNNEL
}

\author{
M.M. DAVIDSON, R.C. BUTLER and D.A.J. TEULON \\ Crop \& Food Research, Private Bag 4704, Christchurch, New Zealand \\ Corresponding author: davidsonm@crop.cri.nz.
}

Western flower thrips females were released into a wind tunnel downwind of a visual and/or odour cue. The number that flew, and of those that flew, the initial direction flown and number that flew onto a sticky trap containing the visual cue were recorded. Thrips responses to visual cues: (i) different colours (yellow, blue, white or transparent), (ii) squares of different sizes $\left(0,0.01,1,4,25\right.$ and $\left.98 \mathrm{~cm}^{2}\right)$ and (iii) different shapes (square, equilateral triangle or circle) for two sizes $\left(4,25 \mathrm{~cm}^{2}\right)$ were recorded. A common floral odour ( $\mathrm{p}$-anisaldehyde) was present for selected sizes in the second experiment. A fourth experiment involved comparing thrips responses to two volumes of the odour $(0.5$ or $1 \mathrm{ml})$ with either a transparent or yellow visual cue $\left(98 \mathrm{~cm}^{2}\right)$. A similar proportion of thrips flew regardless of visual cue colour, size or shape. However, more thrips flew upwind and a larger percentage of thrips that flew landed on the sticky trap when it contained a yellow visual cue $\geq 4 \mathrm{~cm}^{2}$. The percentage that flew upwind and landed on the trap increased with increasing cue size, but there was no difference between shapes. The addition of an odour did not significantly increase the percentage that flew upwind or the percentage landing on the sticky trap.

\section{CHARACTERISATION OF APPLE STEM GROOVING VIRUS IN KIWIFRUIT FROM CHINA}

\author{
G.R.G. CLOVER ${ }^{1,2}$, M.N. PEARSON ${ }^{3}$, D.R. ELLIOTT ${ }^{1}$, Z. TANG ${ }^{1}$, \\ T.E. SMALES ${ }^{1}$ and B.J.R. ALEXANDER ${ }^{1}$ \\ ${ }^{1}$ Ministry of Agriculture and Forestry, National Plant Pest Reference \\ Laboratory, PO Box 2095, Auckland \\ ${ }^{2}$ Current address: Ministry of Agriculture and Forestry, \\ Biosecurity Authority, PO Box 2526, Wellington \\ ${ }^{3}$ School of Biological Sciences, \\ The University of Auckland, Private Bag 92019, Auckland \\ Corresponding author: cloverg@maf.govt.nz.
}

Apple stem grooving virus (ASGV) has been identified in Actinidia chinensis imported from China. Leaf symptoms included inter-veinal mottling, chlorotic mosaics and ringspots. Capillovirus-like particles were observed by electron microscopy and the virus was mechanically transmissible to herbaceous indicators. The virus was detected using an enzyme-linked immunosorbent assay with antisera raised against ASGV. Sequencing of the virus revealed that it had $>95 \%$ amino acid identity with ASGV in the putative coat and movement proteins. From the biological, serological and molecular evidence it was concluded that the virus is a strain of ASGV. It is not known how the strain is transmitted other than by grafting, nor is it known what effect the virus has on the growth of infected vines. The Actinidia-infecting strain of ASGV is not recorded in New Zealand and infected plants will not be released from quarantine. The detection methods used during the research will assist quarantine and the safe movement of breeding material. 